ICMB21

\title{
Performance testing and longterm monitoring of a thermally upgraded Victorian terrace house in the New Bolsover Model Village, Derbyshire.
}

\author{
P.H. Baker ${ }^{\mathrm{a} *}$ and S. Rhee-Duverne ${ }^{\mathrm{b}}$ \\ a Glasgow Caledonian University, Glasgow, UK \\ $b$ Historic England, London, UK
}

\begin{abstract}
To understand the impact on the thermal performance of a Victorian end-of-terrace house and the risks of moisture accumlation after fabric improvements, Historic England carried out whole house thermal performance testing and monitored the moisture conditions at the wallinsulation interface of two internal wall insulation systems on the solid brick walls of the house. Monitoring has been ongoing since December 2011 until January 2019 and the in-situ data has been compared with hygrothermal modelling using WUFI Pro5. The principal goals were to facilitate informed decisions on improving the energy efficiency of traditionally constructed buildings and to understand the potential benefits and unintended consequences of different kinds of adaptation to reduce that energy use, in particular technical risks due to moisture.
\end{abstract}

Peer-review under the responsibility of the organizing committee of the ICMB21.

Keywords: internal wall insulation; thermal performance; moisture risk

\section{Introduction/Background}

New Bolsover Model Village was built by Bolsover Colliery Company in 1891 on the outskirts of Bolsover, Derbyshire, to accommodate their workforce at the nearby Bolsover Colliery. Historic England advised New Bolsover district council in carrying out a package of thermal improvements of an end-of-terrace house in the Model Village, including internal wall insulation (IWI).

Two IWI systems were installed: on the ground floor PIR insulation was used and on the first floor, a vapour permeable system based on wood-fibre insulation and lime plaster. PIR represents the more conventional vapour-checked solutions, as used in new buildings; and is recommended by the Energy Saving Trust [1] to reduce condensation risk. The wood-fibre system represents an approach which is perceived as being more sympathetic for use in traditional solid-walled buildings, benefiting the absorption, transport and release of moisture through the use of hygroscopic materials.

The actual improvement in the thermal performance and airtightness of the building envelope were determined from measurements before and after fabric improvements [2]. To assess risks of moisture accumulation, monitoring of the hygrothermal performance of the building fabric following the installation of two internal wall insulation systems on the solid brick walls of the house has been ongoing since December 2011 until January 2019.

\section{Aims \& Objectives}

The overall aims of the project were:

- To determine the improvement in thermal performance of the building envelope of an end terrace house after interventions to improve its fabric insulation.

- To investigate the risk of condensation and moisture problems within the walls after intervention for the two insulation systems selected, supported by hygrothermal modelling.

- To use the results to inform a strategy for implementing energy efficiency in the house type.

\section{Methodology}

In situ U-value measurements [3] were made in representative locations following a thermal imaging survey in the house, and co-heating and air tightness tests were performed before and after refurbishment. Temperature and relative humidity (RH) sensors were installed in 32 locations at the interface of the cold face of the insulation and the masonry walls, as hygrothermal modelling indicated that the greatest risk of condensation could occur at this location. In addition, resistance measurements converted to moisture contents of small wood blocks at the interface were made to assess the potential risk of moisture damage. The monitored interface temperature and RH results for each elevation were compared with WUFI Pro5 simulations using the measured indoor and outdoor boundary conditions including driving rain to assess the capability of WUFI to model traditional constructions. The procedure included varying the rain adherence factor in the models to improve the match to the in situ measurements.

\footnotetext{
* Corresponding author. +44 7909362486.phowbak@gmail.com.
} 


\section{ICMB21}

\section{Results}

The average solid wall U-value before installation of IWI was $1.7 \mathrm{~W} / \mathrm{m} 2 \mathrm{~K}$. Post intervention the ground floor average wall Uvalue with the PIR system was $0.24 \mathrm{~W} / \mathrm{m} 2 \mathrm{~K}$ and the $1^{\text {st }}$ floor average U-value for the wood-fibre system was $0.33 \mathrm{~W} / \mathrm{m}^{2} \mathrm{~K}$. The air permeability results decreased from $13 \mathrm{~m}^{3} /\left(\mathrm{h} . \mathrm{m}^{2}\right)$ to $10 \mathrm{~m}^{3} /\left(\mathrm{h} . \mathrm{m}^{2}\right)$ at $50 \mathrm{~Pa}$. The whole house thermal transmission was reduced by 44\%. The interface RH results for the two IWI systems are summarised by elevation in Figures 1-3. Peak winter RHs for the more exposed east and west elevations on both floors fall to safe levels below $80 \%$ in spring and summer. $1^{\text {st }}$ floor locations remain at critical RH values for longer before recovering than ground floor locations. The drier west elevation receiving about 50\% more solar radiation than the east which receives an estimated 9\% more driving rain. The gable wall is shaded by its neighbour and interface RHs remain high throughout the monitoring period. Good agreement between simulations and measured data for the east and west elevations for the $1^{\text {st }}$ floor wood-fibre system and for the ground floor west elevation with PIR was achieved by adjusting the rain adherence factor. The modelling results for the gable wall and ground floor east elevation were unsatisfactory, illustrating the difficulty in modelling when the rain adherence factor and the degree of shading are unknown.

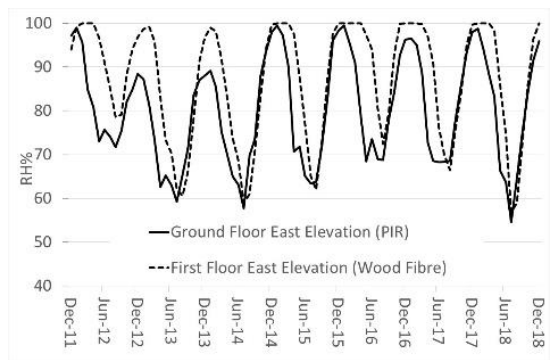

Figure 1. Insulation/masonry interface RH for east elevation

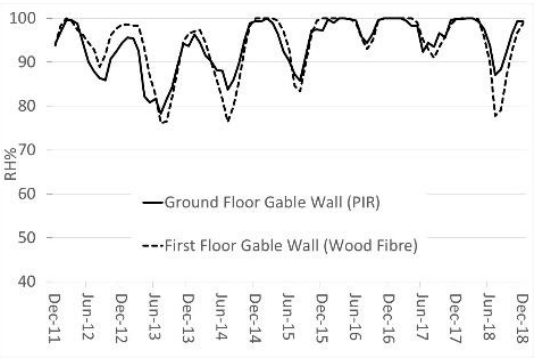

Figure 2. Insulation/masonry interface $\mathrm{RH}$ for gable wall

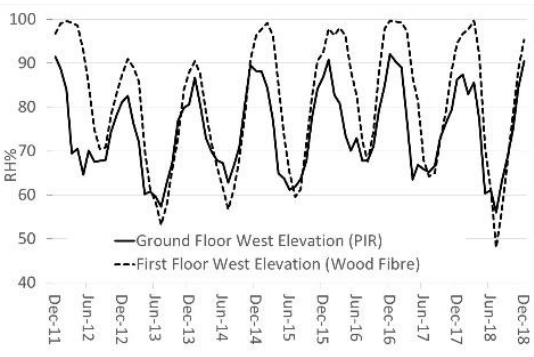

Figure 3. Insulation/masonry interface RH for west elevation

\section{Discussion and Conclusions}

- The works carried out at New Bolsover have resulted in significant energy efficiency improvements with predicted savings determined by SAP [4] of 38\% in the total fuel consumption and $40 \%$ in primary energy use and $38 \%$ reduction in $\mathrm{CO}_{2}$ emissions, and an improvement in SAP band from E to D. The latter, arguably not reflecting the degree of improvement achieved and highlighting problems of SAP calculations.

- Both IWI systems show similar trends in behaviour with strong seasonal cycles, high winter RH in the critical range (>90\%), falling to safe levels during summer. However, the sheltered and shaded measurement locations on the south gable wall show persistently high RHs throughout the year. The results so far indicate that there are generally slightly drier conditions at the IWI-brick wall interface with PIR than the hygroscopic wood-fibre system. First floor locations with the wood-fibre IWI remain at critical $\mathrm{RH}$ values for longer before recovering than equivalent ground floor locations with PIR. The more persistent high RHs are a consequence of the moisture buffering behaviour of the wood-fibre insulation, which can absorb large quantities of moisture but takes longer to dry out. The extent to which this may result in a risk of decay is unclear and needs further investigation including mould risk analysis using isopleths.

- The gable wall results give cause for concern for both IWI systems, suggesting that individual solutions may be needed for different elevations and degree of exposure. Orientation effects which result from exposure to wind and solar radiation are a determining factor in the performance of the walls: the more exposed front and rear elevations tend to be drier than the gable wall, which receives lower level of direct solar radiation. Possible mitigating measures to reduce moisture risk could be by reducing the thickness of insulation and/or by use of a render. Further investigations are underway.

- Good correlation was found between the simulations and the measured data for the east and west wall for the first floor wood-fibre system; however, modelling of south gable wall was less successful. For the PIR on the ground floor, modelling the west elevation was successful, the east elevation rather less so, while the gable results were also generally unsatisfactory.

- The degree of shading of the gable wall, driving rain estimation, variability in the rain adherence factor, and greater uncertainty in the measurements during exposure to RHs above $90 \%$ were some of the contributory factors to the discrepancies between measurement and simulation.

\section{References}

[1] Baker, P. \& S. Rhee-Duverne, A Retrofit of a Victorian Terrace House in New Bolsover: A Whole House Thermal Performance Assessment. 2015. Historic England

[2] EST (2002) Good Practice Guide 138, Internal wall insulation in existing housing - a guide for specifiers and contractors. Energy Saving Trust.

[3] Baker P.H. \& Rhee-Duverne S. (2013), Research into the Thermal Performance of Traditional Brick Walls: In situ U-value Measurements of Solid Brick Walls. Historic England.

[4] SAP 2009 (2011) The Government's Standard Assessment Procedure for Energy Rating of Dwellings 2009 edition incorporating RdSAP 2009. BRE. 